Bull. Chem. Soc. Ethiop. 2018, 32(2), 337-349.

ISSN 1011-3924

(c) 2018 Chemical Society of Ethiopia and The Authors

Printed in Ethiopia

DOI: https://dx.doi.org/10.4314/bcse.v32i2.12

\title{
EFFECTS OF TERNARY METAL ADDITIONS ON CORROSION OF SPARK PLASMA SINTERED Ni-Fe ALLOYS IN $\mathrm{H}_{2} \mathrm{SO}_{4}$ AND NaCI
}

\author{
Mxolisi Brendon Shongwe ${ }^{1}$, Isaac Moraka Makena ${ }^{1}$, Olawale Olarewaju Ajibola ${ }^{2 *}$, Peter Apata \\ Olubambi $^{2}$ and Feyisayo Victoria Adams ${ }^{3}$ \\ ${ }^{1}$ Institute for NanoEngineering Research, Department of Chemical, Metallurgical and Materials \\ Engineering, Tshwane University of Technology, Pretoria, South Africa \\ ${ }^{2}$ Department of Chemical Engineering Technology, University of Johannesburg, Johannesburg, \\ South Africa \\ ${ }^{3}$ Department of Petroleum Chemistry, American University of Nigeria, Yola, Nigeria
}

(Received May 13, 2017; Revised March 17, 2018; Accepted April 9, 2018)

\begin{abstract}
Effect of ternary additions on electrochemical behavior of Ni-Fe binary alloys developed by Spark Plasma Sintering (SPS) were investigated and reported. All specimens revealed common passivity behavior in $\mathrm{H}_{2} \mathrm{SO}_{4}$. Both binary and ternary alloys did not reveal passivity region under saline conditions. The alloys have lower corrosion rates in $\mathrm{NaCl}$ than in $\mathrm{H}_{2} \mathrm{SO}_{4}$. Binary $\mathrm{Ni}_{50} \mathrm{Fe}_{50}$ alloy is characterized by large pits in $\mathrm{H}_{2} \mathrm{SO}_{4}$ and homogeneous corrosion on surface in $\mathrm{NaCl}$. $\mathrm{Ni}_{50} \mathrm{Fe}_{40} \mathrm{Ta}_{10}$ shows better passivity in $1 \mathrm{M} \mathrm{H}_{2} \mathrm{SO}_{4}$ and $\mathrm{Ni}_{50} \mathrm{Fe}_{40} \mathrm{Al}_{10}$ has the lowest corrosion rate in $3.5 \mathrm{wt} . \% \mathrm{NaCl}$.
\end{abstract}

KEY WORDS: Spark plasma sintering, Corrosion, Ni-Fe based alloy, Ternary alloys, Powder metallurgy

\section{INTRODUCTION}

Ni-Fe base alloys have wide applications as parts of devices in pumps, pipeline, turbines, ultrasupercritical (USC) boiler applications, and in active chemical reactors. Unlike previous research studies in Ni-based alloys which were mainly fabricated via vacuum and induction melting [1] with limitations to eliminate sulfur and phosphorus, powdered metallurgical processes of $\mathrm{Ni}-\mathrm{Fe}$ based alloys have more flexibility for compositions not possible by other techniques, high dimensional accuracy, short production time, good chemical homogeneity, and capability to fabricate magnetic components and control of magnetic properties to large extent.

As at the time of reporting this study, not many studies have documented, works on the Nibase alloys produced by spark plasma sintering (SPS). Similarly, the effects of ternary additions as anti-oxidants on the Ni-Fe-base austenitic matrix fabricated by SPS and the corrosion behaviors of sintered Ni-Fe-based alloys in selected media remains unclear. Although the work forms part of a large study to develop Ni-base alloys, it is specially focused on the SPS fabricated $\mathrm{Ni}-\mathrm{Fe}$ base material with investigation of ternary additions on the binary system and concurrently studying their benefits on the corrosion characteristics of the ternary alloys.

This work used an advanced method of sintering that produces highly dense materials at much lower temperature. It is in particular good for those substances that are not easy to sinter by usual sintering processes in which there could be the contamination by the adsorptive gases on the faces of powder particles as a result of localized high-temperature spark impact. The high-speed ion movement between contacting particles probably caused by the applied electric field is mostly held accountable for helping sintering, supporting diffusion and in this manner materials are transferred in both nano and micro scales [2]. Recently researchers have shown that it is possible to sinter a system of Fe-Ni alloys with high densities successfully [3, 4].

*Corresponding author. E-mail: olawalea@uj.ac.za

This work is licensed under the Creative Commons Attribution 4.0 International License 
The present work considers the advantages of the SPS system, the gap in the Ni-Fe based alloy manufacture by SPS process being rarely reported, and in particular researches centered on the corrosion of the Ni-Fe-base sintered alloys. Diverse reports are available on imparts of alloying on the chemical, microstructural and phases characterization/behavior of different type of engineering materials. These include the super-alloys, steels and aluminum alloys [5-7], nickel nano-particles [8] and titanium base alloys, etc., and their corrosion behaviors [9] and control [10-15] in different media [16-18]. The current research development in the Ni-Fe-based austenitic matrix which falls under the category of Ni-based alloys is beginning to receive attention from researchers. The present work aimed at investigating the influence of ternary metal additives (as anti-oxidants on the Ni-Fe-base austenitic matrix) on the corrosion of sintered $\mathrm{Ni}-\mathrm{Fe}$ based alloy using potentiodynamic polarization technique. The electrochemical methods of corrosion testing were conducted in $3.5 \mathrm{wt}$. $\% \mathrm{NaCl}$ and $1 \mathrm{M} \mathrm{H}_{2} \mathrm{SO}_{4}$. The corrosion results were correlated with the different ternary additions and also against the microstructure for all the alloys and their performance discussed.

\section{EXPERIMENTAL}

\section{Material preparation}

Elemental ternary metal powder additions ( $\mathrm{Al}, \mathrm{Co}, \mathrm{Cr}, \mathrm{Mo}, \mathrm{Ta}$ and $\mathrm{Ti}$ ) and commercial elemental powders ( $\mathrm{Ni}$ and $\mathrm{Fe}$ ) were used for this study. Table 1 shows the compositions of the raw powders. The binary $\left(\mathrm{Ni}_{50} \mathrm{Fe}_{50}\right)$ system was weighed accurately and mixed together with the individual ternary additions powders to make up a desired stoichiometric ratio of $\mathrm{Ni}_{50} \mathrm{Fe}_{40} \mathrm{X}_{10}$ (wt.\%) (where $\mathrm{X}=\mathrm{Al}, \mathrm{Co}, \mathrm{Cr}$, Mo, Ta and Ti). Clearly, each $\mathrm{Ni}_{50} \mathrm{Fe}_{40} \mathrm{X}_{10}$ alloy contains $50 \%$ of $\mathrm{Ni}, 40 \%$ of $\mathrm{Fe}$ and $10 \%$ of $\mathrm{X}$ (wt.).

The various blends of $\mathrm{Ni}-\mathrm{Fe}$ and ternary powder additives were made using a Tubular Shaker/Mixer T2F at $49 \mathrm{rpm}$ for $10 \mathrm{~h}$ as the optimum speed and time respectively. The powder was fed into the mixing compartment using a $250 \mathrm{~mL}$ plastic cylinder being $10 \%$ powder filled and agitated under the translational and rotational motions in a dry condition.

Table 1. Characteristics of the raw powders.

\begin{tabular}{|l|l|l|l|}
\hline $\begin{array}{l}\text { Elemental } \\
\text { powder }\end{array}$ & $\begin{array}{l}\text { Purity } \\
(\%)\end{array}$ & Particle size range $(\mu \mathrm{m})$ & Suppliers \\
\hline $\mathrm{Ni}$ & 99.5 & $\geq 0.5$ to $\leq 3.0$ & Wear Tech (PTY) LTD \\
\hline $\mathrm{Fe}$ & 99.9 & $<44$ & Wear Tech (PTY) LTD \\
\hline $\mathrm{Al}$ & 99.7 & $<25$ & TLS Technik GMBH \& Co., Germany \\
\hline $\mathrm{Co}$ & 99.9 & $<44$ & Wear Tech (PTY) LTD \\
\hline $\mathrm{Cr}$ & 99.2 & $<10$ & Wear Tech (PTY) LTD \\
\hline $\mathrm{Mo}$ & 99.9 & $\geq 2$ to $\leq 4$ & CERAC Incorporated, USA \\
\hline $\mathrm{Ta}$ & 99.9 & $<44$ & TLS Technik GMBH \& Co., Germany \\
\hline $\mathrm{Ti}$ & Grade 1 & $<25$ & TLS Technik GMBH \& Co., Germany \\
\hline
\end{tabular}

\section{Sintering of powder mixtures}

The powder blends were sintered using a $30 \mathrm{~mm}$-inner-diameter by $10 \mathrm{~mm}$ high graphite die in the SPS equipment, (model - HHPD-25 from FCT Systeme GmbH Germany) capable of producing $80-100 \mathrm{~mm}$ diameter by $5-8 \mathrm{~mm}$ thickness product size ranges.

To remove the sinter easily and reduce the temperature inhomogeneity considerably, graphite foils $(0.2 \mathrm{~mm}$ thick) were lagged in-between the die, powders and the punches. Also, the die surface was enclosed in a permeable graphite felt (about $10 \mathrm{~mm}$ approx. thick) used as a 
heat resistor, thus minimizing heat loss due to temperature gradient and radiation $[11,12]$. Sintering operation was done in vacuum at constant pressure $(50 \mathrm{MPa})$ and temperature $(1000$ ${ }^{\circ} \mathrm{C}$ ) and was followed by soaking for 10 minutes at $1000{ }^{\circ} \mathrm{C}$ maximum temperature. All cases involved heating from room temperature $\left(25^{\circ} \mathrm{C}\right)$ to the desired temperature varied at a 150 ${ }^{\circ} \mathrm{C} / \mathrm{min}$ heating rate. After each soak time regime, equipment was powered off and the specimens were rapidly cooled to the room temperature. An implanted optical pyrometer was placed $3 \mathrm{~mm}$ from the top of the sample surface to measure the sintering temperature in SPS apparatus, and sintered discs of $30 \mathrm{~mm}$ diameter by $5 \mathrm{~mm}$ thick were produced.

\section{Microstructural characterization}

Specimen surfaces were prepared by grinding and polished to standard thus removing acquired graphite contamination on the surface. The microstructures of polished/ground specimens surface were examined using SEM (FESEM, JSM-7600F, Jeol, Japan) incorporated with EDX facilities (Oxford X-Max), INCA X-Stream2 pulse analyzer software, and secondary electron detectors. The INCA analyzer software was operated at acquisition time $(70 \mathrm{~s})$ and process time $(2 \mathrm{~s})$. The phases in the sintered specimen were analyzed by XRD (PANalytical Empyrean model) with $\mathrm{Cu} \mathrm{K} \alpha$ radiation and analyzer (High score plus software).

\section{Electrochemical behavior studies}

A cell with three electrodes [13] having different electrolytes was used for the electrochemical investigations. To study the corrosion behavior of alloys, acidic and chloride-containing solutions were used to simulate different types of exposure conditions. Thus, the electrolytes used in this study was $3.5 \mathrm{wt} . \% \mathrm{NaCl}$ and $1 \mathrm{M} \mathrm{H}_{2} \mathrm{SO}_{4}$. The specimens were made by joining an insulated copper wire by aluminum tape to a side of the specimen cold mounted in an epoxy resin. The specimen surface was smoothened by grinding using silicon carbide ( $\mathrm{SiC}$ ) grit paper $(120-1400 \mu \mathrm{m})$ and thereafter by polishing with diamond jelly $(3 \mu \mathrm{m})$, distilled water rinsing, degreasing in acetone and warm air drying. The open circuit potential (OCP) and potentiodynamic polarization (PDP) tests were performed to get information on the corrosion behavior of the test materials (Ni-50Fe-10X ( $\mathrm{X}=\mathrm{Al}, \mathrm{Co}, \mathrm{Cr}, \mathrm{Mo}$, Ta or Ti) alloy system).

Dissolution rate becomes equivalent to hydrogen evolution (reduction of $\mathrm{H}^{+}$in the test solution) rate at the corrosion potential $\left(\mathrm{E}_{\text {corr }}\right)$. Therefore, it is within $10 \mathrm{mV}$ more noble or more active than the corrosion potential, where the applied current density is linear function of the electrode potential. Tafel plots are thus, constructed from Tafel constants which are calculated from the anodic and cathodic portions. These plots are then extrapolated to meet at the $\mathrm{E}_{\text {corr }}$. At this point, the value of current density is recorded, and it corresponds to the corrosion rate of the system. The unit of the Tafel constants is V/decade. A decade of current is one order of magnitude.

An Autolab PGSTAT30 potentiostat with counter electrode (graphite rod), reference electrode $(\mathrm{Ag} / \mathrm{AgCl})$ saturated with $3 \mathrm{M} \mathrm{KCl}$, and working electrode (specimen) were utilized. Experiment was set up at room temperature $\left(22 \pm 2{ }^{\circ} \mathrm{C}\right)$. Meanwhile, OCP stabilization was run for 2 hours and PDP curves obtained at $2 \mathrm{mV} \mathrm{s}^{-1}$ scan rate initiated at -1.0 to +2.5 Volts. At equilibrium, the rate of cathodic reaction (hydrogen evolution) is balanced by an alloy dissolution rate. The state is termed corrosion potential $\left(\mathrm{E}_{\mathrm{corr}}\right)$. Thus, with the scanning rate used, on average the observed $\mathrm{E}_{\text {corr }}$ is reported after approximately \pm 6 min. 


\section{RESULTS AND DISCUSSION}

\section{Pre-materials and powder mixtures}

Prior to mixing, the structures of the powders were studied with a field emission scanning electron microscopy (FESEM, JSM-7600F, Jeol, Japan) equipped with EDS features. The examination of morphological features of the eight as-received powders reveals irregular shapes and agglomeration in $\mathrm{Ni}, \mathrm{Co}, \mathrm{Cr}$, Mo and Ta powders; while $\mathrm{Fe}, \mathrm{Al}$ and $\mathrm{Ti}$ powders are spherical shape and non-porous [3]; typical of powders made by gas atomization. The SEM images of (a) $\mathrm{Ni}_{50} \mathrm{Fe}_{50}$, (b) $\mathrm{Ni}_{50} \mathrm{Fe}_{40} \mathrm{Al}_{10}$, (c) $\mathrm{Ni}_{50} \mathrm{Fe}_{40} \mathrm{Co}_{10}$, (d) $\mathrm{Ni}_{50} \mathrm{Fe}_{40} \mathrm{Cr}_{10}$, (e) $\mathrm{Ni}_{50} \mathrm{Fe}_{40} \mathrm{Mo}_{10}$, (f) $\mathrm{Ni}_{50} \mathrm{Fe}_{40} \mathrm{Ta}_{10}$ and $(\mathrm{g}) \mathrm{Ni}_{50} \mathrm{Fe}_{40} \mathrm{Ti}_{10}$ (wt.\%) show that mixed powders are distributed uniformly.

\section{Sintering of powder metal blends}

Powder sintering is regarded as a thermal treatment usually performed below the fusion temperature of the major components of powder compact in order to enhance the mechanical strength and the thermo-chemical integrity [1-4, 11-12]. After compaction, bordering metal powder particles are bonded by cold welds, which offer the compressed particles sufficient mechanical strength to be handled while diffusion processes form and grow necks at these contacting surfaces at the working sintering temperature [14]. The overall microstructure and properties are dependent of the nature and status of the stating raw materials. The metallochemistry is complex as it involves the multidimensional interactions among all the elemental constituents [15]. As parts of the large work, the production procedures of the NiFe alloy; and the effect of sintering parameters (starting powder morphology and particle sizes, heating rate, temperatures, pressure, sintering time, and holding time) [3] on the densification, microstructure and mechanical properties [4] and behavior (wear) have been explained [16]. Thus, in the present research, the study of the corrosion behavior of the spark plasma sintering of NiFe alloy enhanced with ternary additions is being considered.

\section{Electrochemical behavior in $1 \mathrm{M} \mathrm{H}_{2} \mathrm{SO}_{4}$ and $\mathrm{NaCl}$}

Figure 1 shows the results obtained from the potentiometric (open circuit potential) tests of $\mathrm{Ni}_{50} \mathrm{Fe}_{50}$ and $\mathrm{Ni}_{50} \mathrm{Fe}_{40} \mathrm{X}_{10}\left(\mathrm{X}=\mathrm{Al}, \mathrm{Co}, \mathrm{Cr}, \mathrm{Mo}, \mathrm{Ta}\right.$ and Ti) in $1 \mathrm{M} \mathrm{H}_{2} \mathrm{SO}_{4}$. The results show that $\mathrm{Ni} 40 \% \mathrm{Fe}-10 \% \mathrm{Co}$ alloy exhibits the more noble potential throughout the test, while $\mathrm{Ni}_{50} \mathrm{Fe}_{40} \mathrm{Al}_{10}$ showed the lowest potential. The potentials of Ni50Fe and $\mathrm{Ni}_{50} \mathrm{Fe}_{40} \mathrm{X}_{10}(\mathrm{X}=\mathrm{Co}$ and $\mathrm{Ta}$ ) initially increased with time and gradually increased toward a steady state value with exposure time of 2 h. This behavior shows an indication of good passivity in $1 \mathrm{M} \mathrm{H}_{2} \mathrm{SO}_{4}$.

However, it was observed that the potentials values for $\mathrm{Ni}_{50} \mathrm{Fe}_{40} \mathrm{X}_{10}(\mathrm{X}=\mathrm{Mo}$, Ti and $\mathrm{Cr})$ initially decreased and reached minimum values and then gradually increased, while $\mathrm{Ni}_{50} \mathrm{Fe}_{40} \mathrm{Mo}_{10}$ stabilized throughout the $2 \mathrm{~h}$ test. However, the potential of $\mathrm{Ni}_{50} \mathrm{Fe}_{40} \mathrm{Ti}_{10}$ was observed to decrease after about $2300 \mathrm{~s}$. The initial decrease in potential signifies initial corrosion on the surfaces of the alloys and later formation of passive films, which caused the increase in the potentials. It is known that when an oxide of chromium formed a continuous layer on the surface of an alloy, it will hinder or reduce the oxidation process thus, protecting the metal. However, in order to obtain a continuous protective chromia layer, chromium contents has to be more than $18 \%$ in the alloy [17]. The potentials of the alloys after $2 \mathrm{~h}$ of exposure in $1 \mathrm{M} \mathrm{H}_{2} \mathrm{SO}_{4}$ are of the order: $\mathrm{Ni}_{50} \mathrm{Fe}_{40} \mathrm{Co}_{10}>\mathrm{Ni}_{50} \mathrm{Fe}_{40} \mathrm{Mo}_{10}>\mathrm{Ni}_{50} \mathrm{Fe}_{50}>\mathrm{Ni}_{50} \mathrm{Fe}_{40} \mathrm{Ta}_{10}$ $>\mathrm{Ni}_{50} \mathrm{Fe}_{40} \mathrm{Cr}_{10}>\mathrm{Ni}_{50} \mathrm{Fe}_{40} \mathrm{Ti}_{10}>\mathrm{Ni}_{50} \mathrm{Fe}_{40} \mathrm{Al}_{10}$.

The $\mathrm{Ni}_{50} \mathrm{Fe}_{40} \mathrm{Al}_{10}$ showed different behaviors in $1 \mathrm{M} \mathrm{H}_{2} \mathrm{SO}_{4}$ as its potential decreased gradually from the beginning of the test (possibly due to the dissolution of oxide film formed on the surface of the alloy) up to about $20 \mathrm{~min}$ and thereby stabilized throughout the test in a 
similar trend as explained by [18]. Open-circuit potential (OCP) measurements are carried out to study the reactivity of the alloys, that is, their tendencies to corrode in different media with time. Therefore, the more negative is the samples potential, the less thermodynamic stable is the sample in the test solution and thus, corrodes faster. The alloys of $\mathrm{Ni}_{50} \mathrm{Fe}_{40} \mathrm{X}_{10}(\mathrm{X}=\mathrm{Al}$ and Ti) exhibit more negative potentials as compared to others.

For their high reactivity, it is expected that $\mathrm{Ni}_{50} \mathrm{Fe}_{40} \mathrm{X}_{10}(\mathrm{X}=\mathrm{Al}$ and $\mathrm{Ti})$ will be less resistant in the test solution. Although, it is renowned that $\mathrm{Al}$ is much more effective than $\mathrm{Cr}$ in improving oxidation [19], it also exhibits corrosion and scaling resistance by producing $\mathrm{Al}_{2} \mathrm{O}_{3}$

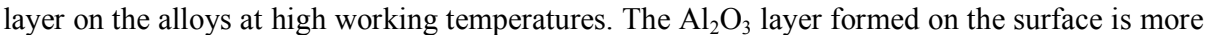
thermodynamically stable and thus, caused no poisoning effect as common with the evaporation of the chromia $\left(\mathrm{Cr}_{2} \mathrm{O}_{3}\right)$ scale [20-22].

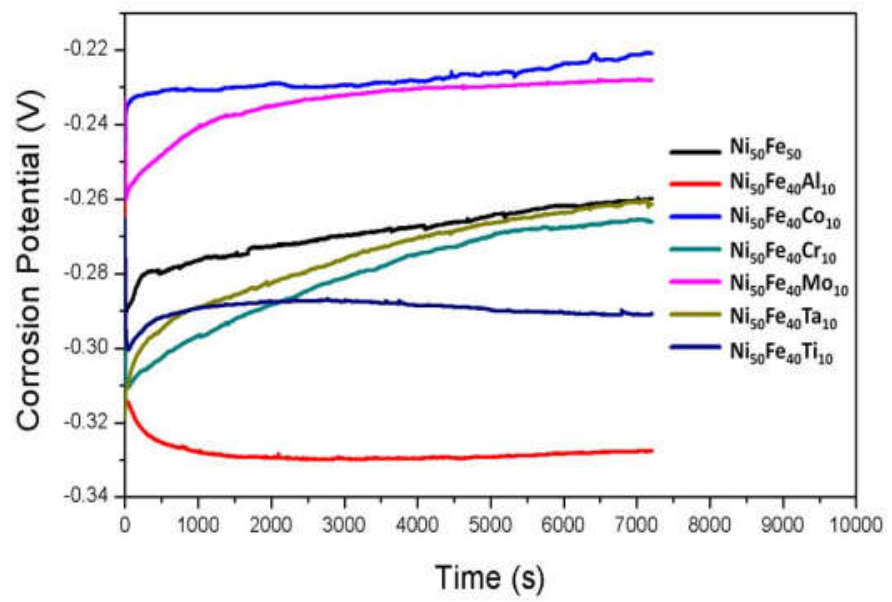

Figure 1. Open-circuit potential of $\mathrm{Ni}_{50} \mathrm{Fe}_{40} \mathrm{X}_{10}$ (wt. \%, $\mathrm{X}=\mathrm{Al}, \mathrm{Co}, \mathrm{Cr}, \mathrm{Mo}$, Ta and Ti) in $1 \mathrm{M}$ $\mathrm{H}_{2} \mathrm{SO}_{4}$.

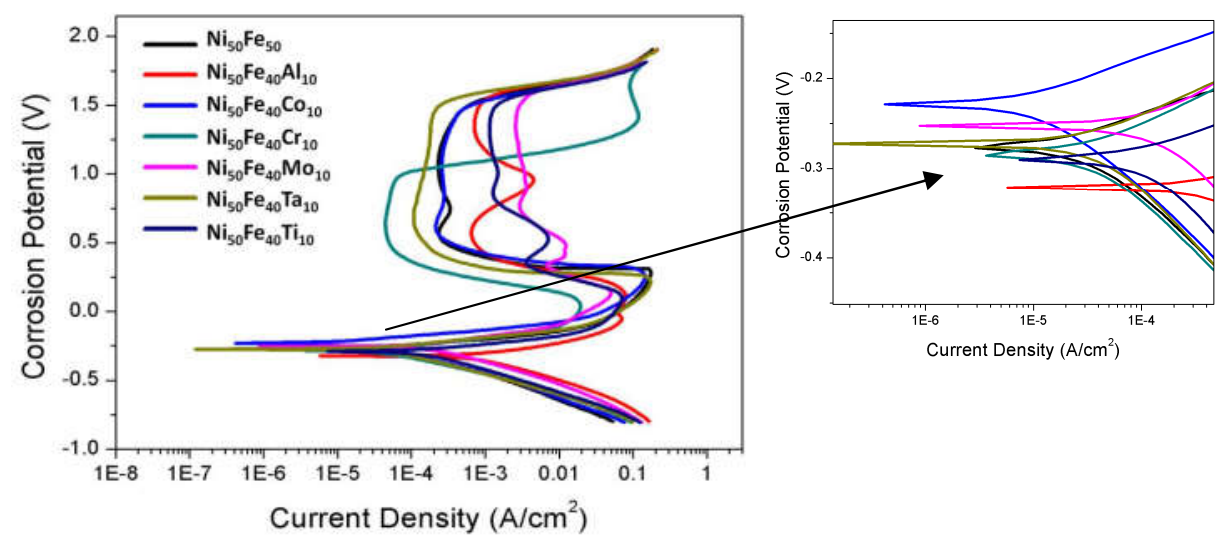

Figure 2. Potentiodynamic polarization curves of $\mathrm{Ni}_{50} \mathrm{Fe}_{40} \mathrm{X}_{10}$ (wt.\%), $\mathrm{X}=\mathrm{Al}, \mathrm{Co}, \mathrm{Cr}, \mathrm{Mo}$, Ta and $\mathrm{Ti}$ ) in $1 \mathrm{M} \mathrm{H}_{2} \mathrm{SO}_{4}$.

Bull. Chem. Soc. Ethiop. 2018, 32(2) 
The polarization behavior of the alloys studied in $1 \mathrm{M} \mathrm{H}_{2} \mathrm{SO}_{4}$ is shown in Figure 2 and the electrochemical data from the electrochemical test are presented in Table 2. The results obtained confirmed the behavior observed in the OCP test. All the alloys show typical passivity behavior in $1 \mathrm{M} \mathrm{H}_{2} \mathrm{SO}_{4}$ and exhibit defined active to passive region as a result of metal oxidation [23] with some irregularity seen in the passivity of $\mathrm{Ni}_{50} \mathrm{Fe}_{40} \mathrm{X}_{10}(\mathrm{X}=\mathrm{Al}, \mathrm{Ti}$, and Mo). This behavior indicates passivation, corrosion and re-passivation of the alloys in the solution. $\mathrm{The} \mathrm{Ni}_{50} \mathrm{Fe}_{40} \mathrm{Ta}_{10}$ alloy shows better passivity. This also was seen in the OCP results in Figure 1 where the alloys displayed more noble potential and passivated with time throughout the $2 \mathrm{~h}$ of test. Contrary to a report that the presence of molybdenum oxyhydroxide or molybdates within the passive films prevents corrosion, Kozhevnikov et al. [24] had shown that that no molybdenum oxides could be formed at the passive potential regions in $\mathrm{HCl}$ and $\mathrm{H}_{2} \mathrm{SO}_{4}$ solutions.

Table 2. Corrosion data obtained from potentiodynamic curves in $1 \mathrm{M} \mathrm{H}_{2} \mathrm{SO}_{4}$ solution.

\begin{tabular}{|l|l|l|l|l|l|l|}
\hline Sample & Ecorr $(\mathrm{V})$ & Icorr $\left(\mathrm{A} / \mathrm{cm}^{2}\right)$ & $\mathrm{Rp}(\mathrm{ohm})$ & $\mathrm{Ba}(\mathrm{V} / \mathrm{dec})$ & $\mathrm{Bc}(\mathrm{V} / \mathrm{dec})$ & $\mathrm{CR}(\mathrm{mm} / \mathrm{y})$ \\
\hline $\mathrm{Ni}_{50} \mathrm{Fe}_{50}$ & -0.221 & $1.66 \times 10^{-5}$ & $2.26 \times 10^{2}$ & 0.039 & 0.177 & $1.86 \times 10^{1}$ \\
\hline $\mathrm{Ni}_{50} \mathrm{Fe}_{40} \mathrm{Al}_{10}$ & -0.326 & $1.21 \times 10^{-3}$ & $8.41 \times 10^{0}$ & 0.114 & 0.204 & $1.34 \times 10^{1}$ \\
\hline $\mathrm{Ni}_{50} \mathrm{Fe}_{40} \mathrm{Co}_{10}$ & -0.228 & $1.03 \times 10^{-4}$ & $7.59 \times 10^{1}$ & 0.075 & 0.192 & $1.15 \times 10^{0}$ \\
\hline $\mathrm{Ni}_{50} \mathrm{Fe}_{40} \mathrm{Cr}_{10}$ & -0.284 & $1.18 \times 10^{-4}$ & $5.01 \times 10^{1}$ & 0.088 & 0.17 & $1.25 \times 10^{0}$ \\
\hline $\mathrm{Ni}_{50} \mathrm{Fe}_{40} \mathrm{Mo}_{10}$ & -0.252 & $4.53 \times 10^{-4}$ & $2.42 \times 10^{1}$ & 0.114 & 0.2 & $4.60 \times 10^{0}$ \\
\hline $\mathrm{Ni}_{50} \mathrm{Fe}_{40} \mathrm{Ta}_{10}$ & -0.272 & $8.82 \times 10^{-5}$ & $5.45 \times 10^{1}$ & 0.068 & 0.163 & $9.55 \times 10^{-1}$ \\
\hline $\mathrm{Ni}_{50} \mathrm{Fe}_{40} \mathrm{Ti}_{10}$ & -0.289 & $1.79 \times 10^{-4}$ & $2.60 \times 10^{1}$ & 0.063 & 0.17 & $2.00 \times 10^{0}$ \\
\hline
\end{tabular}

In Figure 2, broad bands are observed in the region 0.2-1.5 $\mathrm{V}$ which suggests the intense passive regions for the alloys at diverse current densities. The results in Table 2 show that $\mathrm{Ni}_{50} \mathrm{Fe}_{50}$ exhibits more positive potential and lowest corrosion current density $\left(1.66 \times 10^{-5} \mathrm{~A}\right.$ $\mathrm{cm}^{-2}$ ), while $\mathrm{Ni}_{50} \mathrm{Fe}_{40} \mathrm{Al}_{10}$ shows the lowesst corrosion potential and highest corrosion current density. These results also reflect in the corrosion rates of the alloys in $1 \mathrm{M} \mathrm{H}_{2} \mathrm{SO}_{4}$ solution. The $\mathrm{Ni}_{50} \mathrm{Fe}_{50}$ alloy shows the lowest corrosion rate, followed by $\mathrm{Ni}_{50} \mathrm{Fe}_{40} \mathrm{Ta}_{10}$. However, $\mathrm{Ni}_{50} \mathrm{Fe}_{40} \mathrm{Al}_{10}$ alloy shows the highest corrosion rate. This further correlate with the results obtained from the OCP tests. The order of corrosion rates of the alloys in $1 \mathrm{M} \mathrm{H}_{2} \mathrm{SO}_{4}$ solution is: $\mathrm{Ni}_{50} \mathrm{Fe}_{50}<$ $\mathrm{Ni}_{50} \mathrm{Fe}_{40} \mathrm{X}_{10}(\mathrm{X}=\mathrm{Ta}<\mathrm{Co}<\mathrm{Cr}<\mathrm{Ti}<\mathrm{Mo}<\mathrm{Al})$.

\section{Electrochemical behavior in $3.5 \% \mathrm{NaCl}$}

A study on the tendencies of the alloys to be corroded in the $3.5 \% \mathrm{NaCl}$ environment with time was carried out using OCP measurements. The OCP results for the alloys tested in $3.5 \% \mathrm{NaCl}$ are presented in Figure 3. The potentials of alloys $\mathrm{Ni}_{50} \mathrm{Fe}_{50}, \mathrm{Ni}_{50} \mathrm{Fe}_{40} \mathrm{X}_{10}(\mathrm{X}=\mathrm{Cr}, \mathrm{Ta}$ and $\mathrm{Co})$ initially increased, but later decreased with time. An irregular behavior (increase and decrease in potentials) was observed in all the alloys in $3.5 \% \mathrm{NaCl}$. This indicates the formation of unstable passive films on the surface of the alloys. Halogen ions such as chloride ion have the tendency to reduce the potential range of the passive region by lowering the breakdown potential resulting from the penetration and destruction of the passive film by the halogen ions. According to Leffler [25], chloride ion can break down the passive film formed and prevent reformation of new films.

The potentials of the alloys containing $\mathrm{Ni}_{50} \mathrm{Fe}_{40} \mathrm{X}_{10}(\mathrm{X}=\mathrm{Al}$, Mo and $\mathrm{Ti})$ initially decreased. The potential of $\mathrm{Ni}_{50} \mathrm{Fe}_{40} \mathrm{X}_{10}(\mathrm{X}=\mathrm{Al}$ and $\mathrm{Ti})$ alloys increased after about $5 \mathrm{~min}$. and thereafter decreased till the end of the test. At the end of the test, the order of the potentials were $\mathrm{Ni}_{50} \mathrm{Fe}_{40} \mathrm{Co}_{10}>\mathrm{Ni}_{50} \mathrm{Fe}_{40} \mathrm{Ta}_{10}>\mathrm{Ni}_{50} \mathrm{Fe}_{40} \mathrm{Cr}_{10}>\mathrm{Ni}_{50} \mathrm{Fe}_{50}>\mathrm{Ni}_{50} \mathrm{Fe}_{40} \mathrm{Ti}_{10}>\mathrm{Ni}_{50} \mathrm{Fe}_{40} \mathrm{Mo}_{10}>$ $\mathrm{Ni}_{50} \mathrm{Fe}_{40} \mathrm{Al}_{10}$. 
Table 3. Corrosion data obtained from potentiodynamic curves in $3.5 \% \mathrm{NaCl}$ solution.

\begin{tabular}{|l|l|l|l|l|l|l|}
\hline Sample & Ecorr $(\mathrm{V})$ & Icorr $\left(\mathrm{A} / \mathrm{cm}^{2}\right)$ & $\mathrm{Rp}(\Omega)$ & $\beta \mathrm{a}(\mathrm{V} / \mathrm{dec})$ & $\beta \mathrm{c}(\mathrm{V} / \mathrm{dec})$ & $\mathrm{CR}(\mathrm{mm} / \mathrm{y})$ \\
\hline $\mathrm{Ni}_{50} \mathrm{Fe}_{50}$ & -0.408 & $3.45 \times 10^{-6}$ & $1.95 \times 10^{4}$ & 0.383 & 0.327 & $3.87 \times 10^{-2}$ \\
\hline $\mathrm{Ni}_{50} \mathrm{Fe}_{40} \mathrm{Al}_{10}$ & -0.455 & $1.33 \times 10^{-6}$ & $6.53 \times 10^{3}$ & 0.074 & 0.268 & $1.47 \times 10^{-2}$ \\
\hline $\mathrm{Ni}_{50} \mathrm{Fe}_{40} \mathrm{Co}_{10}$ & -0.415 & $4.09 \times 10^{-6}$ & $1.62 \times 10^{4}$ & 0.373 & 0.331 & $4.55 \times 10^{-2}$ \\
\hline $\mathrm{Ni}_{50} \mathrm{Fe}_{40} \mathrm{Cr}_{10}$ & -0.402 & $2.61 \times 10^{-6}$ & $1.34 \times 10^{4}$ & 0.248 & 0.325 & $2.78 \times 10^{-2}$ \\
\hline $\mathrm{Ni}_{50} \mathrm{Fe}_{40} \mathrm{Mo}_{10}$ & -0.448 & $2.08 \times 10^{-6}$ & $1.17 \times 10^{4}$ & 0.157 & 0.286 & $2.11 \times 10^{-2}$ \\
\hline $\mathrm{Ni}_{50} \mathrm{Fe}_{40} \mathrm{Ta}_{10}$ & -0.389 & $2.98 \times 10^{-6}$ & $1.14 \times 10^{4}$ & 0.205 & 0.376 & $3.23 \times 10^{-2}$ \\
\hline $\mathrm{Ni}_{50} \mathrm{Fe}_{40} \mathrm{Ti}_{10}$ & -0.627 & $1.75 \times 10^{-6}$ & $1.69 \times 10^{4}$ & 0.498 & 0.136 & $1.02 \times 10^{-2}$ \\
\hline
\end{tabular}

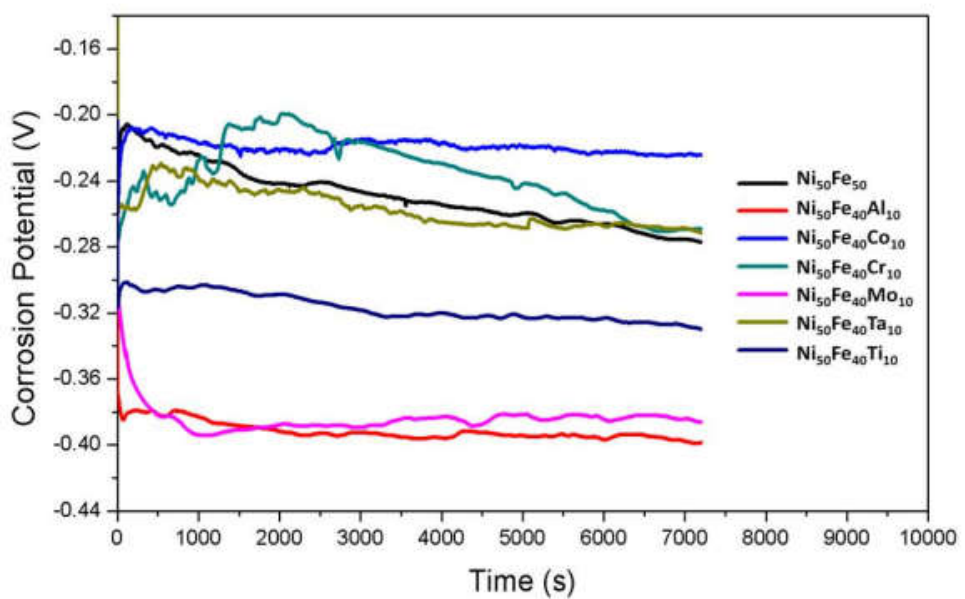

Figure 3. Open-circuit potential of $\mathrm{Ni}_{50} \mathrm{Fe}_{40} \mathrm{X}_{10}(\mathrm{X}=\mathrm{Al}, \mathrm{Co}, \mathrm{Cr}, \mathrm{Mo}$, Ta and $\mathrm{Ti}$ (wt.\%)) in 3.5\% $\mathrm{NaCl}$.

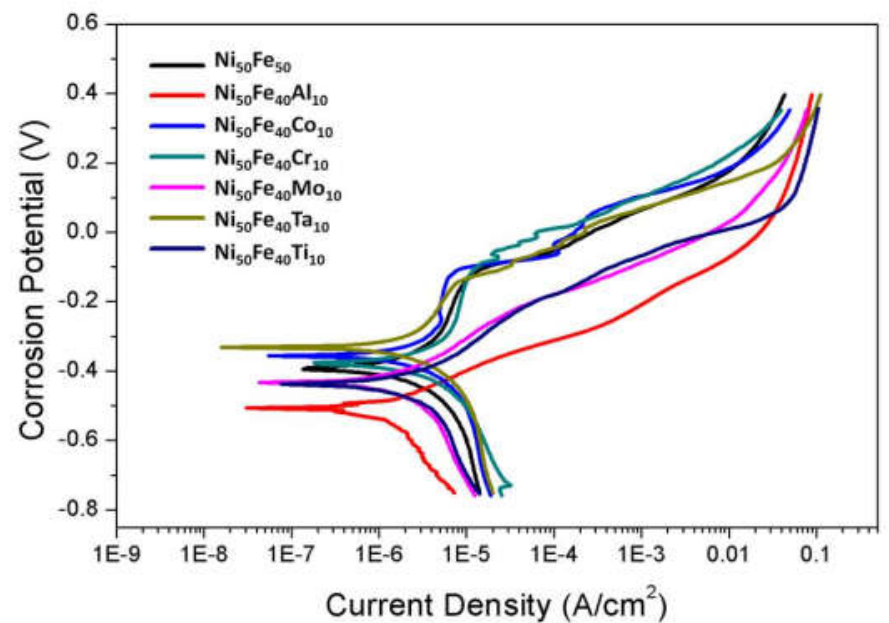

Figure 4. Potentiodynamic polarization curves of $\mathrm{Ni}_{50} \mathrm{Fe}_{40} \mathrm{X}_{10}(\mathrm{X}=\mathrm{Al}, \mathrm{Co}, \mathrm{Cr}, \mathrm{Mo}$, Ta and $\mathrm{Ti}$ (wt. \%)) in $3.5 \% \mathrm{NaCl}$.

Bull. Chem. Soc. Ethiop. 2018, 32(2) 
The behavior of the alloys in $3.5 \% \mathrm{NaCl}$ solution was further studied using polarization technique. The results are presented in Figure 4 with obtained data in Table 3. The $\mathrm{Ni}_{50} \mathrm{Fe}_{40} \mathrm{Co}_{10}$ shows a little of active-to passive-region, but other alloys generally did not show any noticeable active-to-passive behavior in the solution, but passivate spontaneously and directly go into a pseudo-passive state. It was observed that as other elements were alloyed with Ni-Fe, a decrease in anodic and cathodic current densities was observed. This decrease indicates anodic dissolution of the alloys and cathodic hydrogen evolution reaction processes. Unlike the behavior of the alloys in $1 \mathrm{M} \mathrm{H}_{2} \mathrm{SO}_{4}$ solution, addition of other elements to $\mathrm{Ni}$-Fe improved its corrosion resistance in $3.5 \% \mathrm{NaCl}$ solution with $\mathrm{Ni}_{50} \mathrm{Fe}_{40} \mathrm{Al}_{10}$ showing the lowest corrosion rate. The corrosion rates of the alloys in $3.5 \% \mathrm{NaCl}$ solution were lower compared to their corrosion rates in $1 \mathrm{M} \mathrm{H}_{2} \mathrm{SO}_{4}$. The corrosion rates of the alloys in $3.5 \% \mathrm{NaCl}$ are as follows: $\mathrm{Ni}_{50} \mathrm{Fe}_{40} \mathrm{X}_{10}$ $(\mathrm{X}=\mathrm{Ti}<\mathrm{Al}<\mathrm{Mo}<\mathrm{Cr}<\mathrm{Ta})<\mathrm{Ni}_{50} \mathrm{Fe}_{50}<\mathrm{Ni}_{50} \mathrm{Fe}_{40} \mathrm{Co}_{10}$. It was observed that all the alloys generally exhibited lower corrosion rates in chloride solution compared to sulfuric acid solution. Similar observation was made by Ameer et al. [26] and Betova et al. [27] in their report, it was seen that the corrosion rate of the alloy tested was higher in the sulfate containing solution than in the chloride solution.

\section{Micrographs of samples after corrosion in $1 \mathrm{M} \mathrm{H}_{2} \mathrm{SO}_{4}$ and $3.5 \% \mathrm{NaCl}$}

Figure 5 shows SEM images after corrosion in $1 \mathrm{M} \mathrm{H}_{2} \mathrm{SO}_{4}$ at different magnifications. The pits are a result of corroded region after they were exposed in the corrosive environment for the different samples showing an indication of how aggressive was the corrosive solution per sample respectively. For $\mathrm{Ni}_{50} \mathrm{Fe}_{50}$ (Figure 5 (a2)) in $1 \mathrm{M} \mathrm{H}_{2} \mathrm{SO}_{4}$ environment, the alloy is characterized by much larger pits as an indication that the corrosive liquid penetrated much deeper into the sample than just its surface Figure 5 (a.2 and c.2). $\mathrm{Ni}_{50} \mathrm{Fe}_{40} \mathrm{Al}_{10}$ (Figure 5 (b2)) and $\mathrm{Ni}_{50} \mathrm{Fe}_{40} \mathrm{Ti}_{10}$ (Figure 5 (g.2)) at magnifications of $1000 \mathrm{x}$ show that corrosion took place around the grain boundaries.
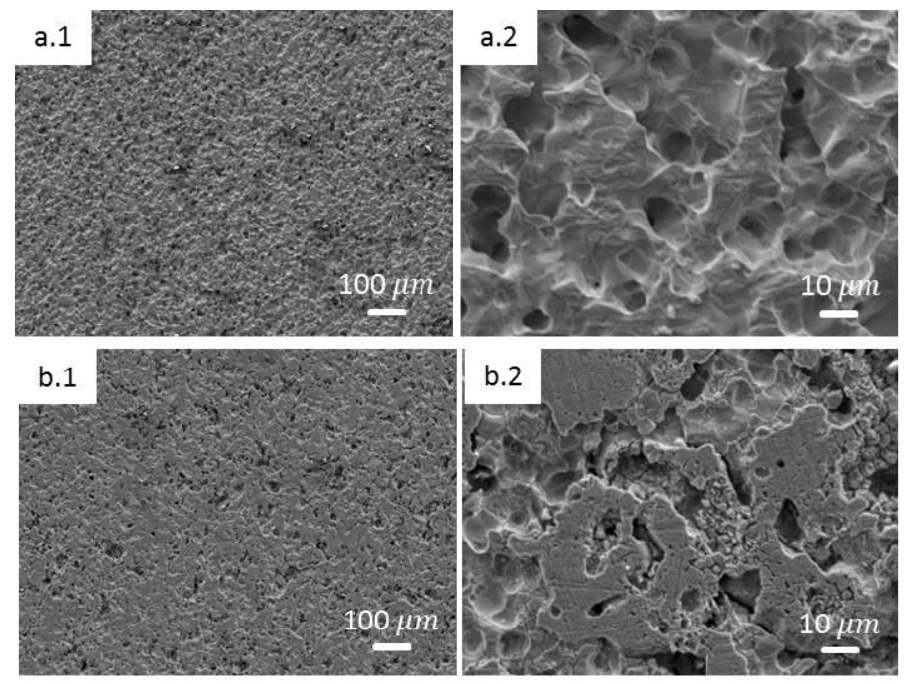

Bull. Chem. Soc. Ethiop. 2018, 32(2) 

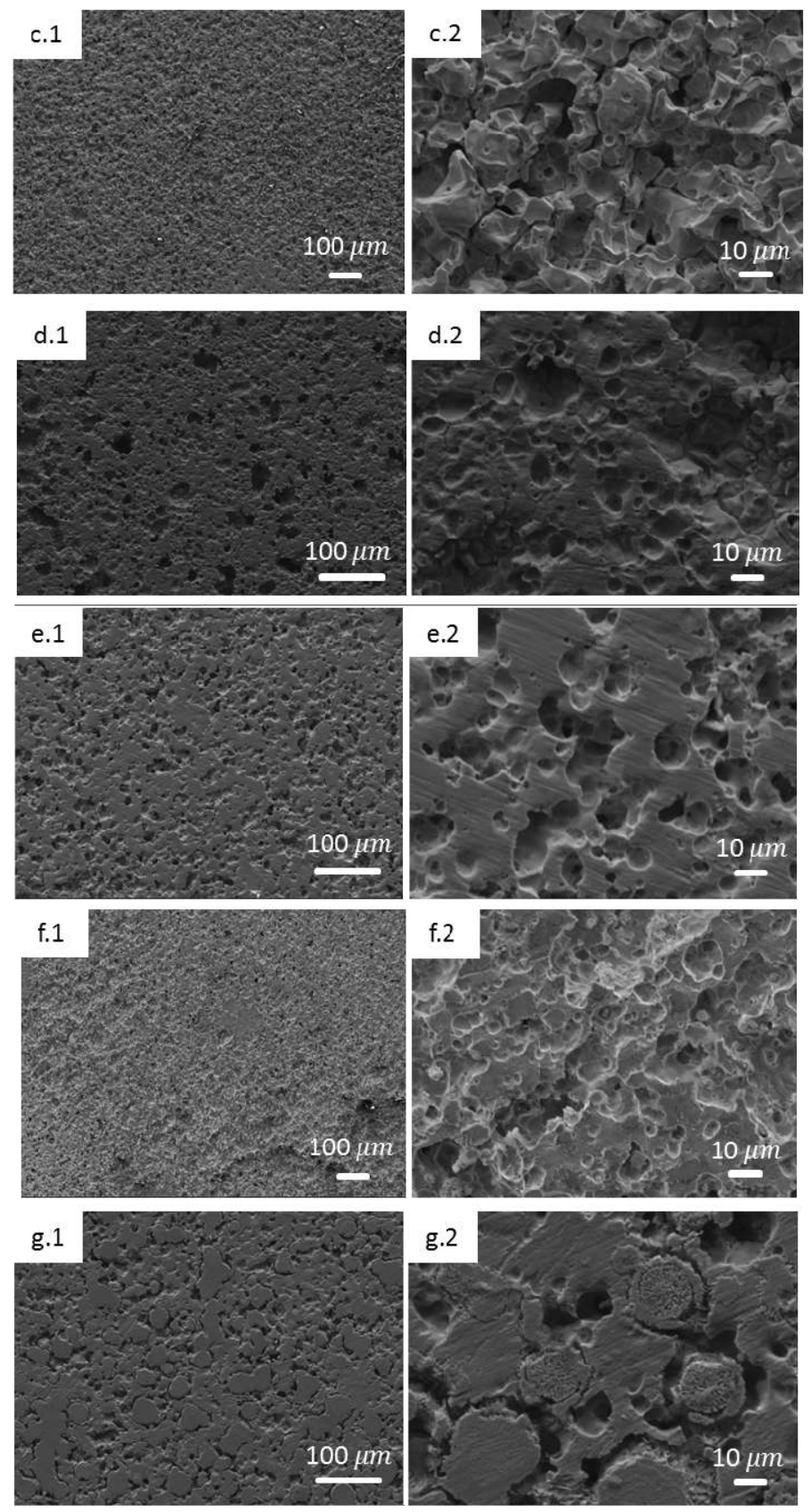

Figure 5. SEM images obtained from the surface of sample after corrosion in $1 \mathrm{M} \mathrm{H}_{2} \mathrm{SO}_{4}$ at different magnifications ((1) 200x and (2)1000x), (a) $\mathrm{Ni}_{50} \mathrm{Fe}_{50}$, (b) $\mathrm{Ni}_{50} \mathrm{Fe}_{40} \mathrm{Al}_{10}$, (c) $\mathrm{Ni}_{50} \mathrm{Fe}_{40} \mathrm{Co}_{10}$, (d) $\mathrm{Ni}_{50} \mathrm{Fe}_{40} \mathrm{Cr}_{10}$, (e) $\mathrm{Ni}_{50} \mathrm{Fe}_{40} \mathrm{Mo}_{10}$, (f) $\mathrm{Ni}_{50} \mathrm{Fe}_{40} \mathrm{Ta}_{10}$, and (g) $\mathrm{Ni}_{50} \mathrm{Fe}_{40} \mathrm{Ti}_{10}$. 
Mxolisi Brendon Shongwe et al.
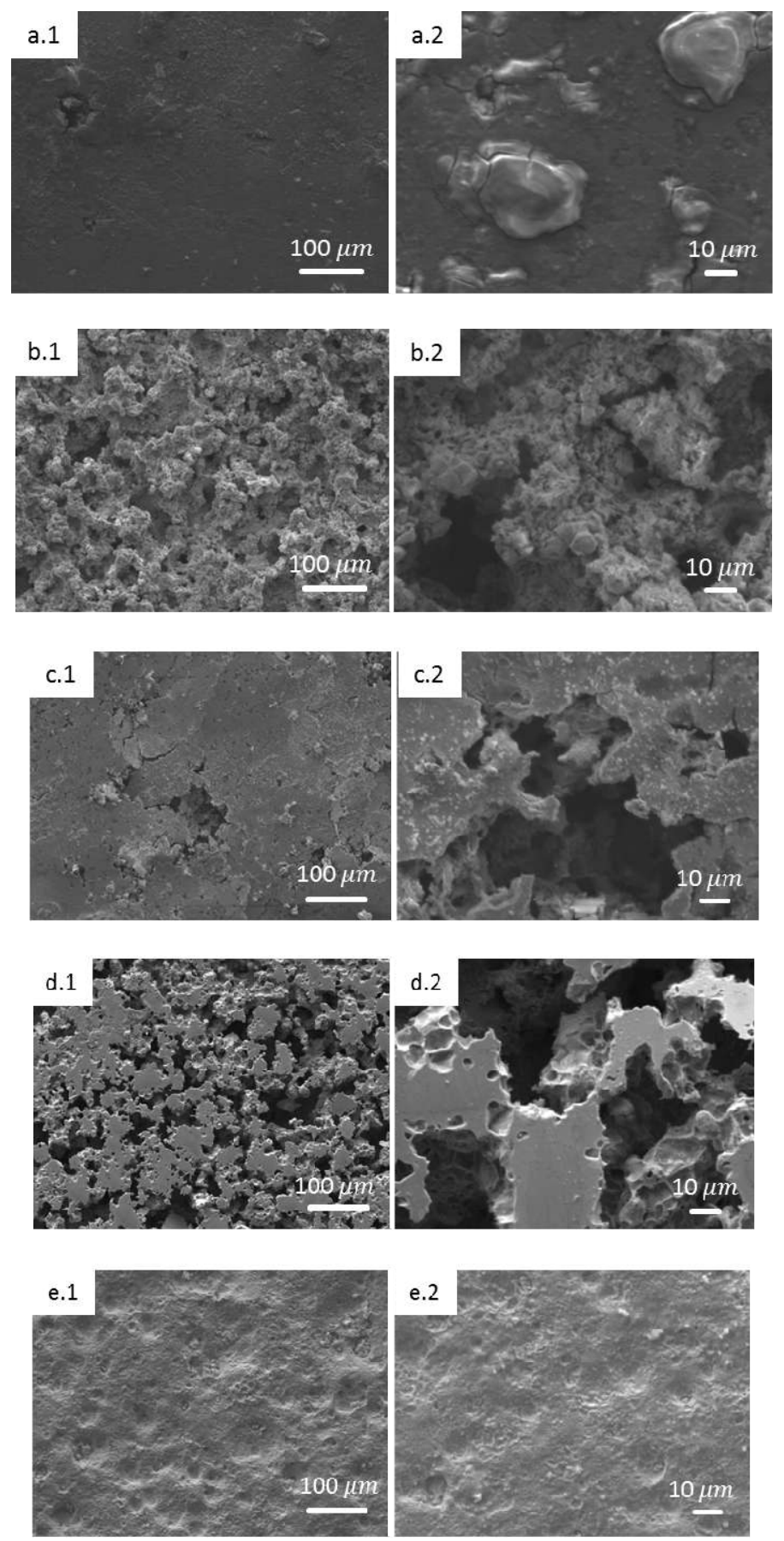

Bull. Chem. Soc. Ethiop. 2018, 32(2) 

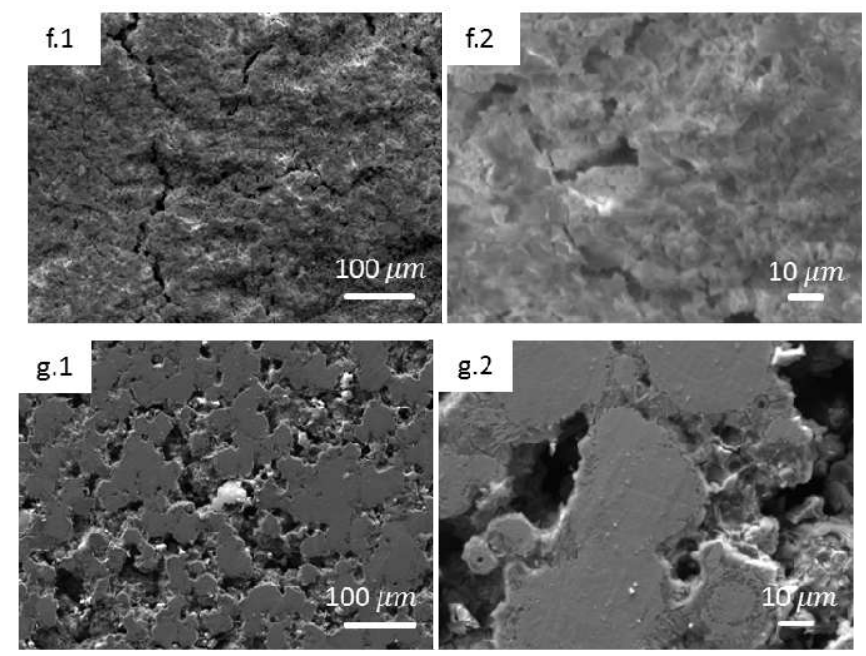

Figure 6. SEM scan obtained from the surface of sample after corrosion in $3.5 \% \mathrm{NaCl}$ at different magnifications ((1) 200x and (2)1000x), (a) $\mathrm{Ni}_{50} \mathrm{Fe}_{50}$, (b) $\mathrm{Ni}_{50} \mathrm{Fe}_{40} \mathrm{Al}_{10}$, (c) $\mathrm{Ni}_{50} \mathrm{Fe}_{40} \mathrm{Co}_{10}$, (d) $\mathrm{Ni}_{50} \mathrm{Fe}_{40} \mathrm{Cr}_{10}$, (e) $\mathrm{Ni}_{50} \mathrm{Fe}_{40} \mathrm{Mo}_{10}$, (f) $\mathrm{Ni}_{50} \mathrm{Fe}_{40} \mathrm{Ta}_{10}$, and (g) $\mathrm{Ni}_{50} \mathrm{Fe}_{40} \mathrm{Ti}_{10}$.

Figure 6 shows SEM images after corrosion in $3.5 \% \mathrm{NaCl}$ at different magnifications. As observed, $\mathrm{Ni}_{50} \mathrm{Fe}_{40} \mathrm{Mo}_{10}$ sample (Figure 6 (e.2)) has the least susceptibility to corrosion. It is corrosion resistant. Molybdenum (Mo) element reacts slowly when exposed to acids because it is a very hard transition metal but is softer and more ductile than Tungsten. $\mathrm{Ni}_{50} \mathrm{Fe}_{40} \mathrm{Al}_{10}$ (Figure 6 (b.2)) also did not suffer much attack since Al produces a protective layer in corrosive environments. $\mathrm{Ni}_{50} \mathrm{Fe}_{50}$ (Figure 6 (a.2)) shows some corrosion oxides that are on top of the surface as shown on 1000x higher magnification. The surface revealed a homogeneously corroded surface. However, weak localized corrosion attacks were observed and were related to the increased porosity due to the detaching of the Ni-Fe particles [28]. In Figure 6 (f.1) $\mathrm{Ni}_{50} \mathrm{Fe}_{40} \mathrm{Ta}_{10}$ sample has visible cracks which were no visible before exposure in the corrosive environment, similarly $\mathrm{Ni}_{50} \mathrm{Fe}_{40} \mathrm{Co}_{10}$ (Figure 6 (c.1 and 2)) has some cracks which is associated with huge material loss and the corrosive environment penetrating much deeper into the sample. $\mathrm{Ni}_{50} \mathrm{Fe}_{40} \mathrm{Cr}_{10}$ (Figure 6 (g.1)) and $\mathrm{Ni}_{50} \mathrm{Fe}_{40} \mathrm{Ti}_{10}$ (Figure 6 (d.1)) corrosion attack took place mainly along the grain boundaries. In most of the alloys corrosion is believed to have progressed or initiated on pre-existing micropores.

\section{CONCLUSION}

Ternary additions of $\mathrm{Al}, \mathrm{Co}, \mathrm{Cr}, \mathrm{Mo}$, Ta and Ti were successfully incorporated into the binary $\mathrm{Ni}_{50} \mathrm{Fe}_{50}$ base alloy by SPS. The Co and Mo additions render an alloy nobler $(\sim-0.23 \mathrm{~V})$ in $\mathrm{H}_{2} \mathrm{SO}_{4}$ solution. However, $\mathrm{Al}$ addition drastically shifted the potential to more negative regions $(\sim-0.33 \mathrm{~V})$. For all the alloys, intense passive region $(\sim 0.25-1.5 \mathrm{~V})$ is seen in the acid medium. $\mathrm{Ni}_{50} \mathrm{Fe}_{40} \mathrm{Cr}_{10}$ showed the lowest passive current density $\left(1 \mathrm{E}-4 \mathrm{~A} / \mathrm{cm}^{2}\right)$ though its potential passive range is low. The addition of $\mathrm{Co}$ and $\mathrm{Cr}$ gave the nobler potentials. In contrast, $\mathrm{Al}$ and Mo showed the lowest potentials. Only $\mathrm{Ni}_{50} \mathrm{Fe}_{40} \mathrm{Co}_{10}$ and $\mathrm{Ni}_{50} \mathrm{Fe}_{40} \mathrm{Cr}_{10}$ alloys showed a short region of active to passive. Nevertheless, $\mathrm{Ni}_{50} \mathrm{Fe}_{40} \mathrm{Al}_{10}$ alloy showed the lowest corrosion rate $\left(\sim 1.02 \times 10^{-2} \mathrm{~mm} / \mathrm{y}\right)$ in $3.5 \% \mathrm{NaCl}$. It was found that the corrosion rate of the alloys in $3.5 \%$ $\mathrm{NaCl}\left(\sim 1.02 \times 10^{-2}-4.55 \times 10^{-2} \mathrm{~mm} / \mathrm{y}\right)$ is lower than in $1 \mathrm{M} \mathrm{H}_{2} \mathrm{SO}_{4}\left(\sim 1.86 \times 10^{-1}-1.34 \times 10^{1}\right.$ $\mathrm{mm} / \mathrm{y})$. 


\section{ACKNOWLEDGMENTS}

This work is based on the research supported in part by the National Research Foundation of South Africa for the grant, Unique Grant No. 99348. Research facilities support by the Institute for NanoEngineering Research, Tshwane University of Technology. O.O. Ajibola thanks the University of Oye Ekiti, Oye-Ekiti, Nigeria, for the study leave.

\section{REFERENCES}

1. Wang, C.; Zhang, W.; Ren C.; Huai, P.; Zhu, Z. The effect of temperature on primary defect formation in Ni-Fe alloy. Nucl. Instr. Meth. Phys. Res. B 2014, 321, 49-53.

2. Suarez, M.; Fernandez, A.; Menendez, J.L.; Torrecillas, R.; Kessel, H.U.; Hennicke, J.; Kirchner, R.; Kessel, T. Challenges and opportunities for spark plasma sintering: A key technology for a new generation of materials in Sintering Applications, Ertuğ B. (Ed.), INTECH OPEN: Online Publications; 2013; pp 319-342. DOI: 10.5772/53706.

3. Shongwe, M.B.; Ramakokovhu, M.M.; Diouf, S.; Durowoju, M.O.; Obadele, B.A.; Sule, R.; Lethabane, M.L.; Olubambi, P.A. Effect of starting powder particle size and heating rate on spark plasma sintering of Fe-Ni alloys. J Alloys Compd. 2016, 678, 241-248.

4. Shongwe, M.B.; Diouf, S.; Durowoju, M.O.; Olubambi, P.A. Effect of sintering temperature on the microstructure and mechanical properties of $\mathrm{Fe}-30 \% \mathrm{Ni}$ alloys produced by spark plasma sintering. J Alloys Compd. 2015, 649, 824-832.

5. Shongwe, M.B.; Diouf, S.; Durowoju, M.O.; Olubambi, P.A.; Ramakokovhu, M.M.; Obadele, B.A. A comparative study of spark plasma sintering and hybrid spark plasma sintering of 93W-4.9 Ni-2.1 Fe heavy alloy. Int. J. Refract. Met. Hard Mater. 2016, 55, 1623.

6. Gassama, D.; Diagne, A.A., Yade, I.; Fall, M.; Faty, S. Investigations on the corrosion of constructional steels in different aqueous and simulated atmospheric environments. Bull. Chem. Soc. Ethiop. 2015, 29, 299-310.

7. Ajibola, O.O.; Oloruntoba, D.T. Effect of MgFeSi inoculant on properties of Cast $6061 \mathrm{Al}$ Alloy for brake master piston application. Indian J. Mater. Sci. 2015, ID 756219, 10 pages.

8. Kalpanadevi, K.; Sinduja, C.R; Manimekalai, R. Synthesis and characterisation of $\mathrm{Ni0} .25 \mathrm{Co} 0.75 \mathrm{Fe}_{2} \mathrm{O}_{4}$ nanostructures. Bull. Chem. Soc. Ethiop. 2016, 30, 79-85.

9. Ajibola, O.O.; Komolafe, D.; Olorunfemi, B. Corrosion of NST60Mn and NST50 steels electroplated with copper in selected water environments. FUOYE J. Eng. Technol. 2016, 1, 67-74.

10. Fayomi, O.S.I.; Popoola, A.P.I.; Monyai, T. Improving the properties of mild steel by ternary multilayer composite coating via electrodeposition route. Bull. Chem. Soc. Ethiop. 2016, 30, 449-456.

11. Räthel, J.; Herrmann, M.; Beckert, W. Temperature distribution for electrically conductive and non-conductive materials during Field Assisted Sintering (FAST). J. Eur. Ceram. Soc. 2009, 29, 1419-1425.

12. Zavaliangos, A.; Zhang, J.; Krammer, M.; Groza J.R. Temperature evolution during field activated sintering. Mater. Sci. Eng. A 2004, 379, 218-228.

13. Culebras, M.; Gómez, C.M.; Cantarero, A. Review on polymers for thermoelectric applications. Materials 2014, 7, 6701-6732.

14. Powder Metallurgy Review Magazine, Sintering in the Powder Metallurgy Process, Powder Metallurgy: The process and its applications. Available at: http://www.pmreview.com/introduction-to-powder-metallurgy/sintering-in-the-powder-metallurgy-process/ Accessed on May 5, 2017. 
15. Ettmayer, P.; Kolaska, H.; Lengauer, W.; Dreyer, K. Ti(C,N) Cermets-metallurgy and properties. Int. J. Refract. Met. Hard Mater. 1995, 13, 1995, 343-351.

16. Makena, M.I.; Shongwe, M.B.; Ramakokovhu, M.M.; Olubambi, P.A. Effect of sintering parameters on densification, corrosion and wear behaviour of Ni-50Fe alloy prepared by spark plasma sintering. J Alloys Compd. 2017, 699, 1166-1179.

17. Slabbert, G.A.; Mulaudzi, F.M.L.; Cornish, L.A.; Papo, M.J.; Morudu, V.; Zhang, J. The effect of the matrix structure on the metal dusting rate in hydrocarbon environments, $J$. $S$. Afr. Inst. Min. Metall. 2013, 113, 81-90.

18. Sherif, E.M.; Potgieter, J.H.; Comins, J.D.; Cornish, L.; Olubambi, P.A.; Machio, C.N. The beneficial effect of ruthenium additions on the passivation of duplex stainless steel corrosion in sodium chloride solutions. Corros. Sci. 2009, 51, 1364.

19. Lu, J.; Yang, Z.; Zhao, X.; Yan, J.; Gu Y. Effect of alloying additions on oxidation behaviors of $\mathrm{Ni}-\mathrm{Fe}$ based superalloy for ultra-supercritical boiler applications. Energy Mater. 2014, 175-184.

20. Galerie, A.; Henry, S.; Wouters, Y.; Mermoux, M.; Petit, J.-P.; Antoni, L. Mechanisms of chromia scale failure during the course of $15-18 \mathrm{Cr}$ ferritic stainless steel oxidation in water vapour. Mater. High Temp. 2005, 22, 105-112.

21. Tortorelli, P. Mechanical properties of chromia scales. J. Physique IV Colloque 1993, 3 (C9), 943-949.

22. Belogolovsky, I.; Hou, P.Y.; Jacobson, C.P.; Visco, S.J. Chromia scale adhesion on 430 stainless steel: Effect of different surface treatments. J. Power Sources 2008, 182, 259-264.

23. Fekry, A.M. The influence of chloride and sulfate ions on the corrosion behavior of Ti and Tie6Ale4V alloy in oxalic acid. Electrochim. Acta 2009, 54, 3480-3489.

24. Kozhevnikov, V.B.; Tsenta, T.E.; Nyazheva, V.M.; Kolotyrkin, Y.M. X-ray photoelectron investigation of the state of the surface of molybdenum polarized in various ranges of potential. Protection of Metals (Zashchita Metallov) 1983, 19, 569-575.

25. Leffler, B. Stainless steels and their properties. Outokumpu Technical Article 2005, 45.

26. Ameer, M.A.; Fekry, A.M.; Heakal, F.E.-T. Electrochemical behavior of passive films on molybdenum-containing austenitic stainless steels in aqueous solutions. Electrochim. Acta 2004, 50, 43-49.

27. Betova, I.; Bojinov, M.; Laitinen, T.; Makela, K.; Pohjanne, P.; Saario, T. The transpassive dissolution mechanism of highly alloyed stainless steels I. Experimental results and modelling procedure. Corros. Sci. 2002, 44, 2675-2697.

28. Mandel, M.; Kruger, L.; Decker, S. Electrochemical corrosion studies of spark plasma sintered zirconia particle reinforced high alloy steel at different temperatures. Corros. Sci. 2015, 90, 323- 330 . 